\title{
Yield and Gap Analysis of Groundnut (Arachis hypogaea L.) Productivity through Frontline Demonstration in District Chittorgarh of Rajasthan, India
}

\author{
Ratan Lal Solanki ${ }^{1^{*}}$ and K.C. Nagar ${ }^{2}$ \\ ${ }^{1}$ KVK, Chittorgarh, ${ }^{2}$ KVK, Bhilwara, Maharana Pratap University of Agriculture and \\ Technology, Udaipur (Rajasthan), India \\ *Corresponding author
}

\section{A B S T R A C T}

\section{Keywords}

Economics,

Extension gap,

FLD, Technology gap, Technology index, Groundnut yield, Technology dissemination

\section{Article Info}

Accepted:

28 May 2020

Available Online:

10 June 2020
Groundnut had played a pivotal role in socio-economic transformation of majority of small and marginal farming community of central India and continued to contribute significantly to the oil economy of India. A study therefore was carried out by Krishi Vigyan Kendra, Chittorgarh (Rajasthan) to know the yield gaps between improved package and practices under front line demonstration (FLD) and farmer's practice (FP) of groundnut crop under rainfed conditions. Front line demonstrations (FLDs) were conducted on total 84 farmer's fields each year to demonstrate the impact of improved agro-techniques on production and economic benefits under rainfed conditions of Chittorgarh in Zone 1V A Sub humid Southern and Plain Arawalli Hills region during Kharif seasons of two consecutive years i.e. 2016-17 to 2017-18. The technologies demonstrated in FLDs recorded additional yield over farmer's practice. Under FLDs the mean grain yield of groundnut was increased by 21.11 per cent over FP. The mean extension gap, technology gap and technology index were calculated as $296 \mathrm{~kg} \mathrm{ha}^{-1}, 311 \mathrm{~kg} \mathrm{ha}^{-1}$ and 15.53 per cent, respectively. Adoption of improved package of practices in groundnut cultivation recorded higher mean B: $\mathrm{C}$ ratio (2.55) as compared to FP (2.33). Yield enhancement and higher net returns observed under FLDs of improved technologies in groundnut. Thus, the productivity of groundnut could be increased with the adoption of recommended improved package of practices. The study resulted to convincing the farming community for higher productivity and returns.

\section{Introduction}

Groundnut (Arachis hypogaea L.) is a self pollinated, annual, herbaceous, autotetrapliod legume with $2 n=40$ chromosomes belonging to the family leguminoseae (Fabaceae). Groundnut is recognized as golden or miracle bean due to its high nutritive value and various usage viz., for feed, oil and soy food products. It is rich in protein $(38-42 \%)$ and contains 18- 22 per cent edible oil. It is known by various names as "wondernut", "Poor man's Cashew nut", "Peanut" "Monkey nut", "Earth nut" or "King of Oilseeds". It is the thirteenth most important food crop of the world; fourth most important source of edible oil and the third most important source of vegetable protein (Sorrensen et al., 2004; Taru et al., 2008). This crop has own importance due to high edible oil content 
and nutritional value of kernel as human food, and haulm as rich feed for animals. Peanut is very important source of oil (4045\%), protein (26\%), carbohydrates (25\%), minerals (Phosphorus, calcium and iron) and vitamins (vitamin B complex like thiamine, riboflavin, niacin and vitamin $\mathrm{E}$ ) in addition to higher proportion of unsaturated fatty acids, including essential fatty acids like linolenic and linoleic acids (Rajbal et al., 2020). Groundnut continues to be number one oilseed crop in India occupying 04.91 million ha area with production of 09.18 million tonnes and productivity $1868 \mathrm{Kg} \mathrm{ha}^{-1}$. Out of which large area of groundnut production is in Rajasthan ie.0.64 million ha and 1.26 million tonnes production with $1966 \mathrm{~kg} \mathrm{ha}^{-1}$ productivity (Anonymous, 2018). The acreage of groundnut in Chittorgarh district was 18344 ha and 30990 metric tonnes production with $1966 \mathrm{~kg} \mathrm{ha}^{-1}$ productivity (Anonymous, 2017-18), receptively. This district has greater potential of groundnut production due to favourable climatic and soil condition. As an exceptional crop among oilseeds, groundnut attained an unparallel glory of its horizontal expansion in very short span of nearly four decades (Dupare et al., 2012). The adoption of recommended production technology among farmers is not very encouraging. The reason may be that either the promising technologies have not yet reached the farmer's fields or farmers are unable to use improved technology due to various socioeconomic reasons. Hence, an efficient technology transfer system is advocated and conducting frontline demonstration on farmer fields have proved as an effective means for creating awareness and acceptance of improved technologies. Keeping this in view, the present study was carried out to find out the yield and gap analysis of groundnut (Arachis hypogaea L.) productivity through frontline demonstration in district Chittorgarh of Rajasthan and effect of technological interventions on groundnut productivity and economics. Groundnut production has to be increased by adopting improved production practices. There are several constraints of low productivity of groundnut in India, out of which poor extension of improved agronomic practices is on the top. Moreover, poor agronomic practices such as higher seed rate, unsuitable new varieties, faulty nutrient management as well as negligence of plant protection measures of crop from insect-pest and wild animals are also responsible for low productivity of groundnut. Frontline demonstration is the modern concept with the objective to demonstrate newly released crop production and protection technologies and its management practices at farmer's fields under different farming situations. While demonstrating the technologies in the farmer's fields, the scientists are required to study the various factors contributing higher crop yield, constraints in field production and thereby generate production data and feedback information. Keeping these in view, FLDs of improved production technology on groundnut were conducted to enhance the productivity and economic returns and also convincing the farmers for adoption of improved production technologies in groundnut crop.

\section{Materials and Methods}

The present study was carried out by Krishi Vigyan Kendra and demonstrations were conducted in its adopted village's viz. Godhakera, Bhutkera Kherpura, Nahargarh, Laxmipura Ram nagar, etc., district Chittorgarh (Rajasthan) in Kharif season of 2016-17 and 2017-18 on the selected farmers' fields. Each demo was conducted in 0.4 ha (one acre) and thus, 84 demonstrations were conducted 2016-17 and 2017-18 year. For the adoption of villages PRA technique and for the selection of farmers the purposive sampling design from frequently organized group meetings was exercised in each village. 
The soils of the farmer fields were rainfed and Silt clay loam in texture and low to medium in NPK. FLD plots were kept for assigning farmers practices. Prior to conducting FLDs, group meeting and specific skill training was given to the selected farmers regarding package of practices of groundnut crop. To popularize the improved groundnut agro techniques for enhancing the production, constraints in groundnut production were identified though participatory approach. Preferential ranking technique was utilized to identify the constraints faced by the respondent farmers in groundnut production. Farmers were also asked to rank the constraints they perceive as limiting factor for groundnut cultivation in order of preference. Based on top rank of farmer's problems identified, front line demonstrations were planned and conducted at the farmer's fields. The improved production-techniques selected for FLDs given in (Table 1). The groundnut crop was sown at $30 \mathrm{~cm}$ (row-row) apart in line using seed rate of $100 \mathrm{~kg} \mathrm{ha}^{-1}$ in month of last June and First week of July during the years, respectively. The average yield of FLD and farmer practice has been taken in the years for interpretation of the results. The extension gap, technology gap and technology index were calculated using the following formula as suggested by Samui et al., (2003).

Extension gap $\left(\mathrm{Kg} \mathrm{ha}{ }^{-1}\right)=$ Demonstration yield $\left(\mathrm{Kg} \mathrm{ha}^{-1}\right)$ - Yield of local check $\left(\mathrm{Kgha}^{-1}\right)$

Technology gap $\left(\mathrm{Kg} \mathrm{ha}^{-1}\right)=$ Potential yield $\left(\mathrm{Kg} \mathrm{ha}^{-1}\right)-$ Demonstration yield $\left(\mathrm{Kg} \mathrm{ha}^{-1}\right)$

Technology index $\%=$

(Potential yield - Demonstration yield) X 100 Potential yield

The data on yield were recorded and analysed for interpretation of the results.

The economic-parameters (gross return, net return and $\mathrm{B}$ : $\mathrm{C}$ ratio) were worked out on the basis of prevailing market prices of inputs and minimum support prices of outputs.

\section{Results and Discussion}

The gap between the existing and recommended technologies of groundnut in Doongla and Begun block district Chittorgarh was presented in (Table 1). Full gap was observed in case of plant protection measure, HYVs, and seed treatment and 50\% gap was observed in case of fertilizer management and weed management whereas, partial gap was observed in use of seed, land preparation, and, which definitely was the reason of not achieving potential yield. Farmers were not aware about recommended technologies. In general, farmers used local or age old varieties instead of the recommended high yielding and disease resistant varieties. Unavailability of seed in time and lack of awareness were the main reasons.

\section{Groundnut yield}

The data on groundnut yield (Table 2) indicated that the FLDs given a good impact on the farming community of Chittorgarh district as they were motivated by the new agricultural technologies adopted in the demonstrations. Average groundnut yield under front line demonstrations was observed as $1690 \mathrm{Kg} \mathrm{ha}^{-1}$ which was higher by $21.11 \%$ over the prevailing farmers practice $(1394 \mathrm{Kg}$ $\left.\mathrm{ha}^{-1}\right)$. The results clearly indicated that the yield of groundnut could be increased over the yield obtained under farmer's practices by accelerating the adoption of recommended production technology for the Chittorgarh districts. Singh et al., (2014), Sharma et al., (2016) and Solanki et al., (2020) also found similar findings. The yield level of control plot was low due to use of low yielding local varieties, improper fertilizers and improper plant population measures. However, in case of demonstration plot, the factors leads to enhance the yield of crop were timely sowing, 
use of new recommended varieties, balanced nutrient management, earthing up seed treatment and plant protection measures.

\section{Extension gap}

More and more use of latest production technologies with high yielding varieties will subsequently change different this alarming trend of galloping extension gap. The new technologies will eventually lead to the farmers to discontinuance of old varieties with the new technology. From these results the extension gap $254 \mathrm{~kg} \mathrm{ha}^{-1}$ in year in 2016$17,337 \mathrm{~kg} \mathrm{ha}^{-1}$ in 2017-18 and average 296 $\mathrm{kg} \mathrm{ha}{ }^{-1}$ was reported (Table 2). During the period of study which emphasized the need to educate the farmers through various means for the adoption of improved agricultural production technologies to reverse this trend of wide extension gap. The technology gap observed may be attributed to the dissimilarity in the soil fertility status and weather conditions. Hence, variety wise location specific recommendation appears to be necessary to minimize the technology gap for yield level in different situations.These finding of studies were in agreement with Singh et al., (2014) Mahadik and Talathi, (2016) and Solanki et al., (2020).

\section{Technology gap}

Data presented in (Table 2) revealed that the maximum technology gap was found in the year 2016-17 (407 $\left.\mathrm{kg} \mathrm{ha}^{-1}\right)$ and lowest in the year 2017-18 (214 $\left.\mathrm{kg} \mathrm{ha}^{-1}\right)$.However, overall average technology gap in the study was 311 $\mathrm{kg} \mathrm{ha}{ }^{-1}$. It was further reported that the technology gap was reduced with respect to succeeding years of experimentation and observed $407 \mathrm{~kg} \mathrm{ha}^{-1}$ in year 2016-17and 214 $\mathrm{kg} \mathrm{ha}^{-1}$ in 2017-18 respectively. It may be attributed to difference in the soil fertility status, agricultural practices, local climate conditions, rainfed agriculture and timeliness of availability of inputs. Hence, variety wise location specific recommendation appears to be necessary to minimize the technology gap for yield level in different farming situations. Hence, location specific recommendations are necessary to bridge the gap. These results are in agreement with Solanki et al., (2013) and Singh et al., (2014).

\section{Technology index}

The technology index indicates the feasibility of evolved technology at the farmer's field. The lower the value of technology index more is the feasibility of the technology. Result of study depicted in (Table 2) revealed that the technology index value was 20.35 per cent in year 2016-17 and 10.70 per cent in 2017-18. On the basis of two years study, the overall technology index 15.53 per cent was recorded, whereas highest technology 20.35 per cent was recorded during 2016-17 and lowest (10.70\%) during 2017-18. Hence, it can be inferred that awareness and adoption of improved varieties with the recommended scientific package of practices have increased during the advancement of the study period. These results are corroborating with the findings of Solanki et al., (2013) and Sharma et al., (2016).

\section{Economic analysis}

The mean higher cost of cultivation Rs. 28700 $\mathrm{ha}^{-1}$ involved in FLDs as compared to Rs. $25900 \mathrm{ha}^{-1}$ under farmers practice (Table 3). The FLDs plots fetched higher mean gross returns (Rs. $73351 \mathrm{ha}^{-1}$ ) and net returns Rs. $44651 \mathrm{ha}^{-1}$ with higher benefit: cost ratio 2.55 as compared to gross returns Rs. $60493.5 \mathrm{ha}^{-1}$, net returns Rs. $34593.5 \mathrm{ha}^{-1}$ and benefit: cost ratio 2.33 with farmers practice. Solanki et al., (2020) also reported higher net returns and B: C ratio in the FLDs on improved technologies compared to the farmers practices and are at par with results of the 
present study which also resulted in higher net returns through FLDs on improved technologies. Similar findings were reported by Solanki et al., (2020).

Table.1 Comparison between technological intervention under FLDs and local check on groundnut

\begin{tabular}{|c|c|c|c|c|}
\hline S.No. & Particulars & FLDs & FP & Gap \\
\hline 1. & $\begin{array}{l}\text { Farming } \\
\text { situation }\end{array}$ & Rainfed & Rainfed & No gap \\
\hline 2. & Variety & $\begin{array}{l}\text { Improved quality seed bunch } \\
\text { variety UG-5 }\end{array}$ & Old variety GG-2 & Gap $(50 \%)$ \\
\hline 3. & $\begin{array}{l}\text { Land } \\
\text { preparation }\end{array}$ & $\begin{array}{l}\text { Summer deep ploughing } \\
\text { followed by rotavator }\end{array}$ & $\begin{array}{l}\text { Summer deep } \\
\text { ploughing followed by } \\
\text { rotavator }\end{array}$ & No gap \\
\hline 4. & Time of sowing & Mid June to July & Mid June to July & No gap \\
\hline 5. & Seed rate & $\begin{array}{l}\text { Use optimum seed rate }(100 \mathrm{~kg} \\
\left.\mathrm{ha}^{-1}\right)\end{array}$ & $\begin{array}{l}\text { Higher seed rate }(125 \\
\left.\mathrm{kg} \mathrm{ha}^{-1}\right)\end{array}$ & $\begin{array}{l}10-20 \% \text { more than } \\
\text { recommendation }\end{array}$ \\
\hline 6. & Seed treatment & $\begin{array}{llr}\text { Seed treatment } & \text { with } \\
\text { trichoderma8 gram } & \mathrm{kg}^{-1} \text { and } \\
\text { bio- fertilizer } & \text { culture } \\
\text { (Rhizobium and PBB) } & \end{array}$ & $\begin{array}{l}\text { No proper seed } \\
\text { treatment }\end{array}$ & Full gap (100\%) \\
\hline 7 & $\begin{array}{l}\text { Method of } \\
\text { sowing }\end{array}$ & Line sowing & Line sowing & No gap \\
\hline 8. & $\begin{array}{l}\text { Fertilizers } \\
\text { Management }\end{array}$ & $\begin{array}{l}\text { Apply SSP fertilizer }(250 \mathrm{~kg} \\
\left.\mathrm{ha}^{-1}\right) \text { and } 25 \mathrm{~kg} \text { urea ha } \mathrm{ha}^{-1} \text { at the } \\
\text { time of sowing }(10 \mathrm{kgN}+40 \mathrm{~kg} \\
\left.\mathrm{P}_{2} \mathrm{O}_{5}+30 \mathrm{~kg} \mathrm{~h}_{\mathrm{S}} \mathrm{ha}^{-1}\right)\end{array}$ & $\begin{array}{lr}\text { Generally } & \text { DAP } \\
\text { fertilizer are } & \text { applied } \\
\left(100 \mathrm{~kg} \mathrm{ha}^{-1}\right) & \end{array}$ & Gap (50\%) \\
\hline 9. & $\begin{array}{l}\text { Weed } \\
\text { Management }\end{array}$ & $\begin{array}{l}\text { Use of herbicides Imazethapyr } \\
\text { 10EC } 100 \text { gram }^{-1} \text { at } 10-15 \\
\text { DAS }\end{array}$ & Manual weeding & Gap (100\%) \\
\hline 10. & $\begin{array}{l}\text { Plant protection } \\
\text { Measure }\end{array}$ & $\begin{array}{l}\text { Plant protection measures } \\
\text { judiciously followed that is } \\
\text { Carbendazim 50WP } 2.0 \mathrm{~kg} \\
\text { against Tikka disease }\end{array}$ & $\begin{array}{l}\text { Plant protection } \\
\text { measure not practices }\end{array}$ & Gap (100\%) \\
\hline
\end{tabular}


Table.2 Yield performance of groundnut under FLDs

\begin{tabular}{|c|c|c|c|c|c|c|c|c|}
\hline \multirow[t]{2}{*}{ Years } & \multirow{2}{*}{$\begin{array}{l}\text { No. of } \\
\text { demonstrati } \\
\text { ons }\end{array}$} & \multirow[t]{2}{*}{$\begin{array}{l}\text { Area( } \\
\text { ha) }\end{array}$} & \multicolumn{2}{|c|}{$\begin{array}{c}\text { Yield } \\
\left(\text { kgha }^{1}\right)\end{array}$} & \multirow{2}{*}{$\begin{array}{l}\text { \% Yield } \\
\text { increase } \\
\text { over FP }\end{array}$} & \multirow{2}{*}{$\begin{array}{c}\text { Extension } \\
\text { gap (kg } \\
\left.\text { ha }^{-1}\right)\end{array}$} & \multirow{2}{*}{$\begin{array}{l}\text { Technolo } \\
\text { gical gap } \\
\left(\mathrm{kg} \mathrm{ha}^{-1}\right)\end{array}$} & \multirow[t]{2}{*}{$\begin{array}{c}\text { Technology } \\
\text { index }(\%)\end{array}$} \\
\hline & & & FLD & FP & & & & \\
\hline 2016-17 & 24 & 9.6 & 1593 & 1339 & 18.96 & 254 & 407 & 20.35 \\
\hline 2017-18 & 60 & 24.5 & 1786 & 1449 & 23.26 & 337 & 214 & 10.70 \\
\hline Mean & 84 & 34.1 & 1690 & 1394 & 21.11 & 2.96 & 311 & 15.53 \\
\hline
\end{tabular}

Table.3 Economics, additional cost and returns in groundnut under frontline demonstrations (FLDs) vs. framers practice (FP)

\begin{tabular}{|c|c|c|c|c|c|c|c|c|c|c|}
\hline \multirow[t]{3}{*}{ Years } & \multirow{2}{*}{\multicolumn{2}{|c|}{$\begin{array}{l}\text { Cost of cultivation } \\
\left(\mathrm{Rs} \mathrm{ha}^{-1}\right)\end{array}$}} & \multirow{2}{*}{\multicolumn{2}{|c|}{$\begin{array}{l}\text { Gross returns } \\
\left(\text { Rs. ha }{ }^{-1}\right)\end{array}$}} & \multirow{2}{*}{\multicolumn{2}{|c|}{ Net returns $\left(\right.$ Rs ha $\left.^{-1}\right)$}} & \multirow{3}{*}{$\begin{array}{l}\text { Additional } \\
\text { cost of } \\
\text { cultivation } \\
\text { (Rs ha }{ }^{-1} \text { in } \\
\text { FLD }\end{array}$} & \multirow{3}{*}{$\begin{array}{c}\text { Additional } \\
\text { returns } \\
\left(\mathrm{Rs} \mathrm{ha}^{-1}\right) \\
\text { in FLD }\end{array}$} & \multicolumn{2}{|c|}{ B: C Ratio } \\
\hline & & & & & & & & & \multirow[t]{2}{*}{ FLD } & \multirow[t]{2}{*}{ FP } \\
\hline & FLD & FP & FLD & FP & FLD & FP & & & & \\
\hline 2016-17 & 27200 & 25400 & 67225 & 56506 & 40025 & 31106 & 1800 & 27200 & 2.47 & 2.22 \\
\hline 2017-18 & 30200 & 26400 & 79427 & 64481 & 49217 & 38081 & 3800 & 30 & 2.63 & 2.44 \\
\hline Mean & 28700 & 25900 & 73351 & 60493.5 & 44651 & 34593.5 & 2800 & 28700 & 2.55 & 2.33 \\
\hline
\end{tabular}

\section{Additional cost of cultivation and returns}

Data (Table 3) revealed that the average additional cost of cultivation (Rs. $2800 \mathrm{ha}^{-1}$ ) under integrated crop management demonstrations and has yielded additional net returns of Rs. $28700 \mathrm{ha}^{-1}$. The results suggest that higher profitability and economic viability of groundnut demonstrations under local agro-ecological situation.

Thus, it may be concluded that the yield and returns in groundnut crop increased substantially with the improved production technologies. However, the yield level under FLDs was better than the farmer practice and performance of these varieties UG-5 could be further improved by adopting recommended production technologies. So, there is need to disseminate the improved technologies among the farmers with effective extension methods like training and field demonstrations. The farmers should be encouraged to adopt the recommended agro-techniques for getting maximum returns in specific locations and use varieties developed by Maharana Pratap
University of Agriculture and Technology, Udaipur (Rajasthan), India have higher yield potential on farmer's field. Thus, it was clearly showed that the demonstration of groundnut with full package was better to farmer's practices. The results indicated that the frontline demonstration has given a good impact on the farming community of the district Chittorgarh (Rajasthan) as they were motivated by the new agricultural technology applied in the FLD plots. Similar findings were reported by Joshi et al., (2014).

\section{Acknowledgement}

Authors sincerely thankful to all the farmers on whose field frontline demonstration were conducted. The financial assistance provided by Indian Council for Agricultural Research, New Delhi and Director, ICAR -Agricultural Application Research Institute (ATRI), ZoneII, Jodhpur (Rajasthan) India. The opinions expressed in this paper are the author's own and do not necessarily reflect the views of the donor or the authors' institution. 


\section{References}

Anonymous, 2017-18. Rajasthan Statistics at a Glance. Commission rate of Agriculture, Rajasthan, Jaipur pp.105.

Anonymous, (2018). Statistics at a Glance of India. Ministry of Agriculture and Farmers Welfare, Government of India, New Delhi, pp.107-109.

Joshi, N.S., Bariya, M.K. and Kunjadia, B.B. (2014). Yield gap analysis through front line demonstrations in rapeseed-mustard crop. International J. Scientific Res. Vol. 4(9): 1-3.

Mahadik, R.P. and Talathi, M.S. 2016. Impact of front line demonstrated organized by Krishi Vigyan Kendra, Roha. Indian J. Ex. Educ. \& R.D.Vol.24: 162-175.

Sorrensen, R., Butts, C., Lamb, M. and Rowland, D. 2004. Five Years of Subsurface Drip Irrigation on Peanut. Research and Extension Bulletin No. 2004.

Samui, S., K. Maitra, S., Roy, D., K. Mandal, A., K. and Saha, D. (2003). Evaluation of front line demonstration on ground nut. Journal of the Indian Society Coastal Agricultural Research, 18 (2): 180-183.

Taru, V.B., Khagya, I.Z., Mshelia, S.I. and Adebayo, E.F. (2008).Economic efficiency of resource use in groundnut production in Adamawa State of Nigeria. World Journal of Agricultural
Science 56: 4896- 9000

Rajbala Sharma, Sarita, Jitendra Singh Bamboriya and S. S. Yadav. (2020). Effect of Integrated Phosphorus Management on Growth and Yield of Groundnut (Arachis hypogaea L.). Int.J.Curr.Microbiol.App.Sci. 9 (4): 1079-1088

Solanki, R.L. and C.L. Khatik (2013). Performance of $\mathrm{HYV}$ of summer groundnut through front line demonstration in Chittorgarh of Rajasthan. International Journal of plant science. Vol. 8 (2): 466-467.

Ratan Lal Solanki, K. C. Nagar, S. K. Agarwal, Priyanyka Swami and Deepa Indoria (2020). Evaluation of Yield Performance of Soybean [Glycine max (L.) Merrill] through Cluster FrontLine Demonstrations. Int.J.Curr.Microbiol. App.Sci. 9 (4): 2617-2624

Sharma, V., Kumar, V., Sharma, S.C. and Singh, S. (2016). Productivity enhancement and popularization of improved production technologies in wheat through frontline demonstrations. Journal of Applied and Natural Science. 8 (1): 423- 428.

Singh, S.R.K., Mishra, A., Gautam, U.S., Dwivedi, A.P. and Chand, Prem (2014). Scouting technological vis-a-vis extension gaps in soybean production in Madhya Pradesh. Indian Res. J. Ext. Edu. 14 (2), May, 2014.

\section{How to cite this article:}

Ratan Lal Solanki and Nagar, K.C. 2020. Yield and Gap Analysis of Groundnut (Arachis hypogaea L.) Productivity through Frontline Demonstration in District Chittorgarh of Rajasthan, India. Int.J.Curr.Microbiol.App.Sci. 9(06): 4119-4125. doi: https://doi.org/10.20546/ijcmas.2020.906.483 